\title{
Key time series
}

\section{National Accounts aggregates}

Last updated 28/09/10

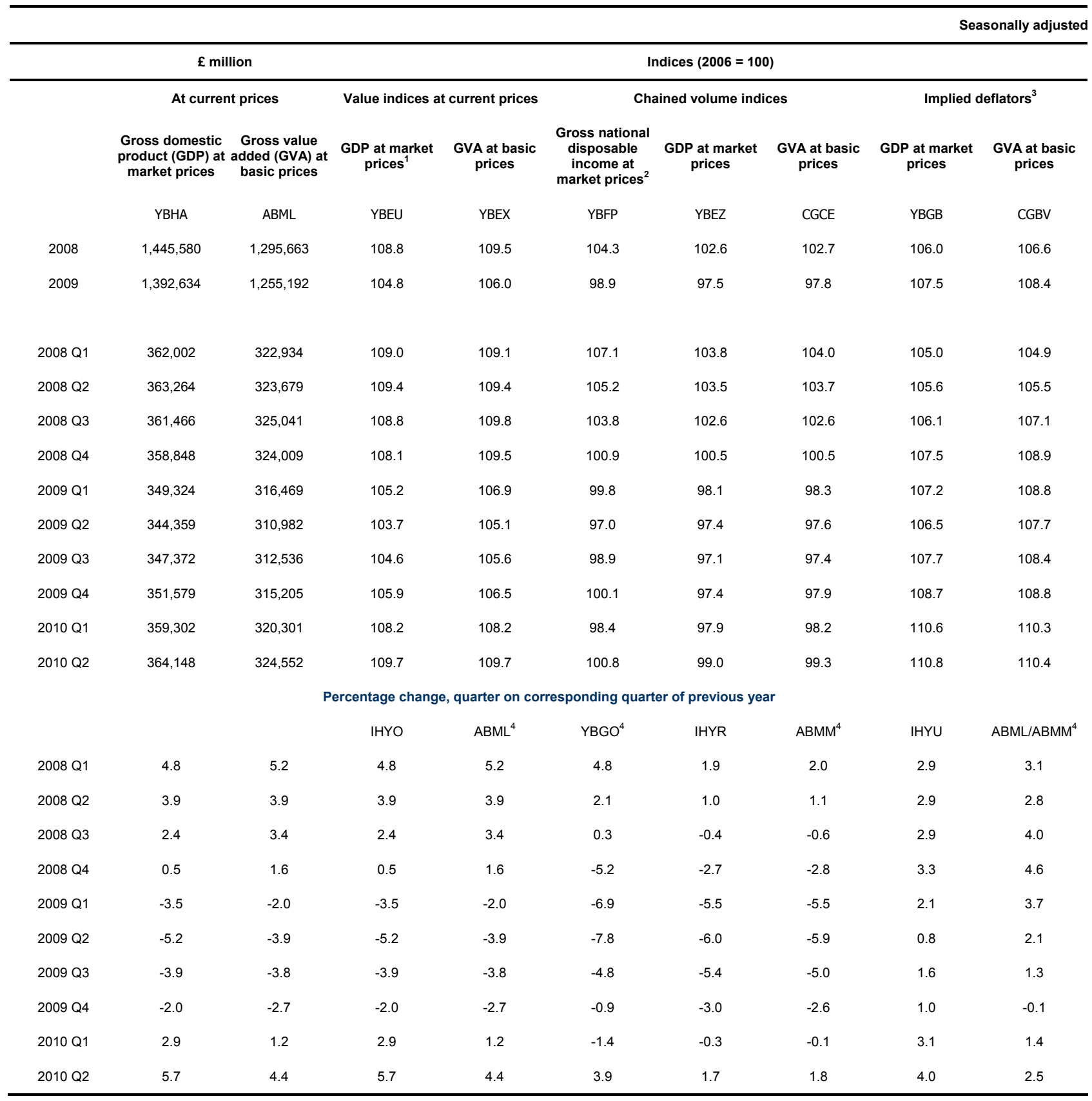

Notes

1. 'Money GDP'

2. This series is only updated once a quarter, in line with the full quarterly national accounts data set

3. Based on chained volume measures and current price estimates of expenditure components of GDP

4. Derived from these identification (CDID) codes. 
2. Gross Domestic Product: by category of expenditure

Last updated 28/09/10

£ million, chained volume measures, reference year 2006, seasonally adjusted

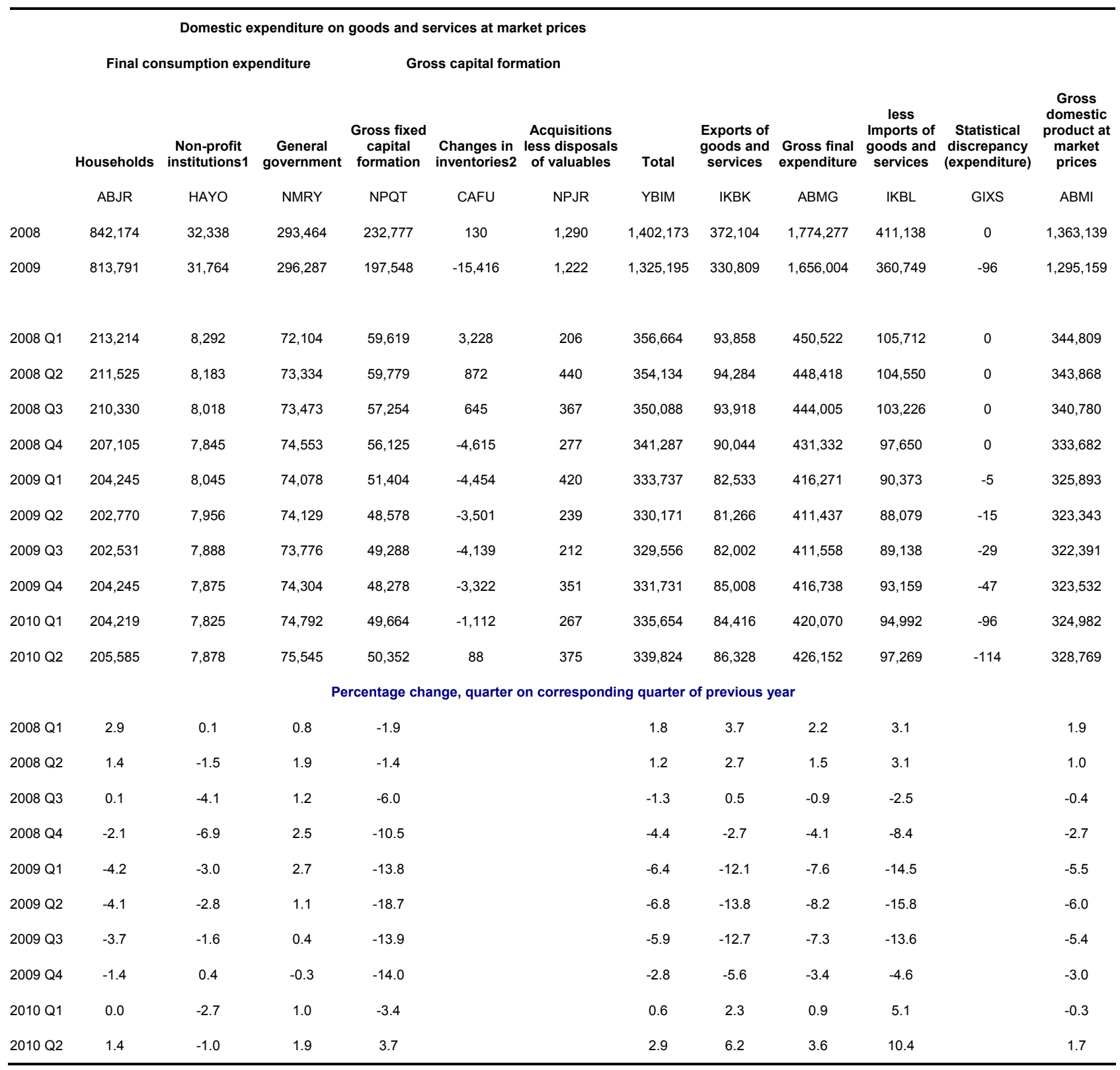

Notes

1. Non-profit institutions serving households

2. This series includes a quarterly alignment adjustment 


\section{Labour Market summary}

Last updated 15/09/10

\begin{tabular}{|c|c|c|c|c|c|c|c|c|}
\hline \multicolumn{9}{|c|}{ United Kingdom (thousands) seasonally adjustec } \\
\hline & \multirow{3}{*}{\multicolumn{2}{|c|}{ LFS household population ${ }^{1}$}} & \multicolumn{6}{|c|}{ Headline indicators } \\
\hline & & & \multicolumn{2}{|c|}{ Employment } & \multicolumn{2}{|c|}{ Unemployment } & \multicolumn{2}{|c|}{ Inactivity } \\
\hline & & & Level & Rate $^{2}$ & Level & Rate $^{3}$ & Level & Rate $^{4}$ \\
\hline & All aged $16 \&$ over & All aged 16 to 64 & All aged $16 \&$ over & All aged 16 to 64 & All aged $16 \&$ over & All aged 16 to 64 & All aged $16 \&$ over & All aged 16 to 64 \\
\hline People & MGSL & LF2O & MGRZ & LF24 & MGSC & MGSX & LF2M & LF2S \\
\hline May-Jul 2008 & 49,070 & 39,579 & 29,503 & 72.8 & 1,717 & 5.5 & 9,065 & 22.9 \\
\hline May-Jul 2009 & 49,450 & 39,803 & 28,857 & 70.7 & 2,472 & 7.9 & 9,233 & 23.2 \\
\hline Aug-Oct 2009 & 49,548 & 39,854 & 28,906 & 70.6 & 2,485 & 7.9 & 9,248 & 23.2 \\
\hline Nov-Jan 2010 & 49,646 & 39,905 & 28,861 & 70.4 & 2,443 & 7.8 & 9,396 & 23.5 \\
\hline Feb-Apr 2010 & 49,744 & 39,955 & 28,872 & 70.3 & 2,475 & 7.9 & 9,422 & 23.6 \\
\hline May-Jul 2010 & 49,842 & 40,006 & 29,158 & 70.7 & 2,467 & 7.8 & 9,264 & 23.2 \\
\hline Change on quarter & 98 & 51 & 286 & 0.4 & -8 & -0.1 & -158 & -0.4 \\
\hline Change on quarter $\%$ & 0.2 & 0.1 & 1.0 & & -0.3 & & -1.7 & \\
\hline Change on year & 393 & 204 & 301 & 0.1 & -5 & -0.1 & 31 & 0.0 \\
\hline Change on year \% & 0.8 & 0.5 & 1.0 & & -0.2 & & 0.3 & \\
\hline Men & MGSM & YBTG & MGSA & MGSV & MGSD & MGSY & YBSO & YBTM \\
\hline May-Jul 2008 & 23,890 & 19,689 & 15,935 & 78.7 & 1,011 & 6.0 & 3,199 & 16.2 \\
\hline May-Jul 2009 & 24,093 & 19,803 & 15,435 & 75.7 & 1,529 & 9.0 & 3,294 & 16.6 \\
\hline Aug-Oct 2009 & 24,148 & 19,830 & 15,408 & 75.4 & 1,535 & 9.1 & 3,360 & 16.9 \\
\hline Nov-Jan 2010 & 24,202 & 19,858 & 15,355 & 75.0 & 1,505 & 8.9 & 3,476 & 17.5 \\
\hline Feb-Apr 2010 & 24,257 & 19,885 & 15,389 & 75.0 & 1,511 & 8.9 & 3,468 & 17.4 \\
\hline May-Jul 2010 & 24,311 & 19,912 & 15,610 & 75.8 & 1,452 & 8.5 & 3,375 & 17.0 \\
\hline Change on quarter & 55 & 27 & 221 & 0.8 & -58 & -0.4 & -93 & -0.5 \\
\hline Change on quarter \% & 0.2 & 0.1 & 1.4 & & -3.8 & & -2.7 & \\
\hline Change on year & 218 & 109 & 175 & 0.1 & -77 & -0.5 & 81 & 0.3 \\
\hline Change on year \% & 0.9 & 0.5 & 1.1 & & -5.0 & & 2.5 & \\
\hline Women & MGSN & LF2P & MGSB & LF25 & MGSE & MGSZ & LF2N & LF2T \\
\hline May-Jul 2008 & 25,180 & 19,890 & 13,568 & 67.0 & 707 & 4.9 & 5,866 & 29.5 \\
\hline May-Jul 2009 & 25,357 & 19,999 & 13,422 & 65.6 & 942 & 6.6 & 5,939 & 29.7 \\
\hline Aug-Oct 2009 & 25,400 & 20,023 & 13,497 & 65.9 & 950 & 6.6 & 5,888 & 29.4 \\
\hline Nov-Jan 2010 & 25,444 & 20,047 & 13,506 & 65.8 & 938 & 6.5 & 5,920 & 29.5 \\
\hline Feb-Apr 2010 & 25,487 & 20,071 & 13,483 & 65.6 & 964 & 6.7 & 5,954 & 29.7 \\
\hline May-Jul 2010 & 25,531 & 20,095 & 13,548 & 65.7 & 1,015 & 7.0 & 5,888 & 29.3 \\
\hline Change on quarter & 44 & 24 & 65 & 0.1 & 50 & 0.3 & -66 & -0.4 \\
\hline Change on quarter $\%$ & 0.2 & 0.1 & 0.5 & & 5.2 & & -1.1 & \\
\hline Change on year & 174 & 95 & 126 & 0.1 & 72 & 0.4 & -50 & -0.4 \\
\hline Change on year \% & 0.7 & 0.5 & 0.9 & & 7.7 & & -0.8 & \\
\hline
\end{tabular}


Notes

1. The Labour Force Survey (LFS) is a survey of the population of private households, student halls of residence and NHS accommodation.

2. The headline employment rate is the number of people aged 16 to 64 in employment divided by the population aged 16 to 64 .

3. The headline unemployment rate is the number of unemployed people (aged 16+) divided by the economically active population (aged 16+). The economically active population is defined as those in employment plus those who are unemployed.

4. The headline inactivity rate is the number of people aged 16 to 64 divided by the population aged 16 to 64 .

\section{Note on headline employment, unemployment and inactivity rates}

The headline employment and inactivity rates are based on the population aged 16 to 64 but the headline unemployment rate is based on the economically active population aged 16 and over. The employment and inactivity rates for those aged 16 and over are affected by the inclusion of the retired population in the denominators and are therefore less meaningful than the rates for those aged from 16 to 64 . However, for the unemployment rate for those aged 16 and over, no such effect occurs as the denominator for the unemployment rate is the economically active population which only includes people in work or actively seeking and able to work.

\section{Note on headline employment, unemployment and inactivity levels}

The headline employment and unemployment levels are for those aged 16 and over; they measure all people in work or actively seeking and able to work. However, the headline inactivity level is for those aged 16 to 64 . The inactivity level for those aged 16 and over is less meaningful as it includes elderly people who have retired from the labour force. 


\section{Prices}

Last updated 15/09/10

\begin{tabular}{|c|c|c|c|c|c|c|c|c|c|c|}
\hline \multicolumn{11}{|c|}{ Percentage change over 12 months, Not seasonally adjusted } \\
\hline & \multicolumn{6}{|c|}{ Consumer prices } & \multicolumn{4}{|c|}{ Producer prices } \\
\hline & \multicolumn{3}{|c|}{ Consumer prices index (CPI) } & \multicolumn{3}{|c|}{ Retail prices index (RPI) } & \multicolumn{2}{|c|}{ Output prices } & \multicolumn{2}{|c|}{ Input prices } \\
\hline & All items & $\begin{array}{l}\text { CPI excluding } \\
\text { indirect taxes } \\
\quad(\mathrm{CPIY})^{1}\end{array}$ & $\begin{array}{c}\text { CPI at constant } \\
\text { tax rates (CPI- } \\
\text { CT) }\end{array}$ & All items & $\begin{array}{l}\text { All items } \\
\text { excluding } \\
\text { mortgage } \\
\text { interest } \\
\text { payments } \\
\text { (RPIX) }\end{array}$ & $\begin{array}{l}\text { All items } \\
\text { excluding } \\
\text { mortgage } \\
\text { interest } \\
\text { payments and } \\
\text { indirect taxes } \\
(\text { RPIY) }\end{array}$ & All manufactured & $\begin{array}{l}\text { Excluding food, } \\
\text { beverages, } \\
\text { tobacco and } \\
\text { petroleum } \\
\text { products }\end{array}$ & $\begin{array}{l}\text { Materials and fuels } \\
\text { purchased by } \\
\text { manufacturing } \\
\text { industry }\end{array}$ & $\begin{array}{l}\text { Excluding food, } \\
\text { beverages, } \\
\text { tobacco and } \\
\text { petroleum } \\
\text { products }\end{array}$ \\
\hline & D7G7 & EL2S & EAD6 & CZBH & CDKQ & CBZX & $\mathrm{PLLU}^{3}$ & PLLv $v^{3,4}$ & $\mathrm{RNNK}^{3,4}$ & $\mathrm{RNNQ}^{3,4}$ \\
\hline 2009 Jan & 3.0 & 4.5 & 4.1 & 0.1 & 2.4 & 3.4 & 3.5 & 4.0 & 1.7 & 10.8 \\
\hline 2009 Feb & 3.2 & 4.6 & 4.2 & 0.0 & 2.5 & 3.5 & 3.0 & 3.7 & 0.8 & 8.9 \\
\hline 2009 Mar & 2.9 & 4.3 & 3.9 & -0.4 & 2.2 & 3.2 & 2.0 & 3.2 & -0.4 & 7.5 \\
\hline $2009 \mathrm{Apr}$ & 2.3 & 3.8 & 3.4 & -1.2 & 1.7 & 2.7 & 1.3 & 2.5 & -5.8 & 2.6 \\
\hline 2009 May & 2.2 & 3.6 & 3.3 & -1.1 & 1.6 & 2.6 & -0.3 & 1.2 & -8.8 & 0.2 \\
\hline 2009 Jun & 1.8 & 3.1 & 2.9 & -1.6 & 1.0 & 1.9 & -1.0 & 0.3 & -12.0 & -2.9 \\
\hline $2009 \mathrm{Jul}$ & 1.8 & 3.1 & 2.8 & -1.4 & 1.2 & 2.1 & -1.3 & 0.2 & -12.2 & -3.4 \\
\hline 2009 Aug & 1.6 & 2.9 & 2.7 & -1.3 & 1.4 & 2.3 & -0.3 & 0.8 & -7.7 & -2.1 \\
\hline 2009 Sep & 1.1 & 2.2 & 2.1 & -1.4 & 1.3 & 2.0 & 0.4 & 1.3 & -6.2 & -1.2 \\
\hline 2009 Oct & 1.5 & 2.6 & 2.5 & -0.8 & 1.9 & 2.8 & 1.8 & 2.1 & 0.5 & 0.9 \\
\hline 2009 Nov & 1.9 & 3.0 & 2.9 & 0.3 & 2.7 & 3.5 & 2.9 & 2.0 & 4.2 & 0.8 \\
\hline 2009 Dec & 2.9 & 2.8 & 2.6 & 2.4 & 3.8 & 3.8 & 3.5 & 2.5 & 7.4 & 1.1 \\
\hline 2010 Jan & 3.5 & 1.9 & 1.7 & 3.7 & 4.6 & 3.3 & 3.8 & 2.6 & 7.7 & 1.4 \\
\hline 2010 Feb & 3.0 & 1.4 & 1.2 & 3.7 & 4.2 & 2.9 & 4.2 & 3.0 & 7.8 & 2.4 \\
\hline 2010 Mar & 3.4 & 1.8 & 1.6 & 4.4 & 4.8 & 3.5 & 5.0 & 3.7 & 10.5 & 4.4 \\
\hline $2010 \mathrm{Apr}$ & 3.7 & 2.0 & 1.9 & 5.3 & 5.4 & 3.9 & 5.9 & 4.5 & 12.8 & 6.3 \\
\hline 2010 May & 3.4 & 1.7 & 1.6 & 5.1 & 5.1 & 3.8 & 5.5 & 4.4 & 11.7 & 7.2 \\
\hline 2010 Jun & 3.2 & 1.6 & 1.5 & 5.0 & 5.0 & 3.8 & 5.1 & 5.0 & 10.6 & 7.1 \\
\hline $2010 \mathrm{Jul}$ & 3.1 & 1.4 & 1.3 & 4.8 & 4.8 & 3.5 & 5.0 & 4.7 & 10.8 & 7.6 \\
\hline 2010 Aug & 3.1 & 1.4 & 1.3 & 4.7 & 4.7 & 3.4 & 4.7 & 4.6 & 8.1 & 6.4 \\
\hline
\end{tabular}

Notes

1 The taxes excluded are VAT, duties, insurance premium tax, air passenger duty and stamp duty on share transactions. 2 The taxes excluded are council tax, VAT, duties, vehicle excise duty, insurance premium tax and air passenger duty. 3 Derived from these identification (CDID) codes.

4 These derived series replace those previously shown. 


\section{Notes to tables}

Identification (CDID) codes

The four-letter identification code at the top of each data column is the ONS reference for this series of data on our time series database. Please quote the relevant code if you contact us requiring any further information about the data.

\section{Conventions}

Where figures have been rounded to the final digit, there may be an apparent slight discrepancy between the sum of the constituent items and the total as shown. Although figures may be given in unrounded form to facilitate the calculation of percentage changes, rates of change etc by users, this does not imply that the figures can be estimated to this degree of precision as they may be affected by sampling variability or imprecision in estimation methods.

The following standard symbols are used:

..

$-$

$\mathrm{P}$

$\mathrm{R}$

$r$ not available

nil or negligible (less than half the final digit shown)

provisional

break in series

revised

series revised from indicated entry onwards

\section{Labour market statistics concepts and definitions}

\section{Labour Force Survey 'monthly' estimates}

Labour Force Survey (LFS) results are three-monthly averages, so consecutive months' results overlap. Comparing estimates for overlapping three-month periods can produce more volatile results, which can be difficult to interpret.

Labour force summary table

\section{Economically active}

People aged 16 and over who are either in employment or unemployed.

\section{Economically inactive}

People who are neither in employment nor unemployed. This includes those who want a job but have not been seeking work in the last four weeks, those who want a job and are seeking work but not available to start work, and those who do not want a job.

\section{Employment and jobs}

There are two ways of looking at employment: the number of people with jobs, or the number of jobs. The two concepts are not the same as one person can have more than one job. The number of people with jobs is measured by the Labour Force Survey (LFS) and includes people aged 16 or over who do paid work (as an employee or self-employed), those who have a job that they are temporarily away from, those on government-supported training and employment programmes, and those doing unpaid family work. The number of jobs is measured by workforce jobs and is the sum of employee jobs (as measured by surveys of employers), self-employment jobs from the LFS, people in HM Forces, and government-supported trainees. Vacant jobs are not included.

\section{Unemployment}

The number of unemployed people in the UK is measured through the Labour Force Survey following the internationally agreed definition recommended by the ILO (International Labour Organisation) - an agency of the United Nations. Unemployed people:

are without a job, want a job, have actively sought work in the last four weeks and are available to start work in the next two weeks, or

are out of work, have found a job and are waiting to start it in the next two weeks 
Other key indicators

Claimant count

The number of people claiming Jobseeker's Allowance benefits.

\section{Earnings}

A measure of the money people receive in return for work done, gross of tax. It includes salaries and, unless otherwise stated, bonuses but not unearned income, benefits in kind or arrears of pay.

\section{Productivity}

Whole economy output per worker is the ratio of Gross Value Added (GVA) at basic prices and Labour Force Survey (LFS) total employment. Manufacturing output per filled job is the ratio of manufacturing output (from the Index of Production) and productivity jobs for manufacturing (constrained to LFS jobs at the whole economy level).

\section{Redundancies}

The number of people who:

were not in employment during the reference week, and

reported that they had been made redundant in the month of, or the two calendar months prior to, the reference week plus the number of people who:

were in employment during the reference week, and

started their job in the same calendar month as, or the two calendar months prior to, the reference week, and reported that they had been made redundant in the month of, or the two calendar months prior to, the reference week

\section{Unit wage costs}

A measure of the cost of wages and salaries per unit of output.

\section{Vacancies}

The statistics are based on ONS's Vacancy Survey of businesses. The survey is designed to provide comprehensive estimates of the stock of vacancies across the economy, excluding those in agriculture, forestry and fishing. Vacancies are defined as positions for which employers are actively seeking recruits from outside their business or organisation. More information on labour market concepts, sources and methods is available in the Guide to Labour Market Statistics at www.statistics.gov.uk/about/data/guides/LabourMarket/default.asp 